\title{
Use of Electrogastrography in Preclinical Studies of Cholinergic and Anticholinergic Agents in Experimental Pigs
}

\author{
J. KVĚTINA ${ }^{1,2}$, I. TACHECÍ ${ }^{1}$, M. PAVLÍK ${ }^{3}$, M. KOPÁČOVÁ ${ }^{1}$, S. REJCHRT ${ }^{1}$, T. DOUDA ${ }^{1}$, \\ M. KUNE $\check{S}^{4}$, J. BURE $\check{S}^{1}$
}

${ }^{1}$ Second Department of Internal Medicine - Gastroenterology, Charles University in Prague, Faculty of Medicine in Hradec Králové and University Teaching Hospital, Hradec Králové, Czech Republic, ${ }^{2}$ Institute of Experimental Biopharmaceutics, Czech Academy of Sciences, Hradec Králové, Czech Republic, ${ }^{3}$ Centre of Advanced Studies, University of Defence, Faculty of Military Health Services, Hradec Králové, Czech Republic, ${ }^{4}$ Biomedical Research Centre, University Teaching Hospital, Hradec Králové, Czech Republic

Received March 29, 2015

Accepted July 6, 2015

On-line December 15, 2015

\section{Summary}

Electrogastrography (EGG) is a non-invasive method for the assessment of gastric myoelectrical activity. Porcine EGG is comparable with human one. The purpose of this study was to evaluate the effect of atropine and neostigmine on the EGG in experimental pigs. Adult female pigs were administrated atropine (1.5 mg i.m., $n=6$ ) and neostigmine (0.5 mg i.m., $n=6$ ) after the baseline EGG, followed by a 90-min trial recording (MMS, Enschede, the Netherlands). Running spectral analysis was used for the evaluation. The results were expressed as dominant frequency of slow waves and EGG power (areas of amplitudes). Neostigmine increased continuously the dominant frequency and decreased significantly the EGG power. Atropine did not change the dominant frequency significantly. However, atropine increased significantly the EGG power (areas of amplitudes) from basal values to the maximum at the $10-20$-min interval. After that period, the areas of amplitudes decreased significantly to the lowest values at the 60-90-min interval. In conclusion, cholinergic and anticholinergic agents affect differently EGG in experimental pigs.

\section{Key words}

Electrogastrography - Experimental pigs - Atropine • Neostigmine

\section{Corresponding author}

J. Květina, 2nd Department of Internal Medicine Gastroenterology, University Teaching Hospital, Sokolská 581,
50005 Hradec Králové, Czech Republic. Fax: +420 495834785. E-mail: kvetina@uebf.cas.cz

\section{Introduction}

Surface electrogastrography (EGG) is a noninvasive method for clinical assessment of gastric myoelectrical activity (Chen 1994, Jackson et al. 2000, Parkman et al. 2003, Koch and Stern 2004, Bureš et al. 2007, 2008). Our group has demonstrated that EGG is also reliable and feasible in experimental pigs (Varayil et al. 2009, Květina et al. 2010, Tachecí et al. 2013). Porcine EGG is fully comparable with that recorded in healthy humans (Varayil et al. 2009, Tachecí et al. 2013). Previously, we studied EGG in experimental pigs under different conditions, like general anesthesia (Tachecí et al. 2013), volume challenge (Tachecí et al. 2014), atropine administration (Bureš et al. 2014a) or the effect of different prokinetics (Varayil et al. 2009, Tachecí et al. 2011, Douda et al. 2014). Other EGG studies in experimental setting (in pigs or dogs) are quite exceptional so far (Mintchev et al. 1993, Koenig et al. 2009, O'Grady et al. 2009).

Our current research has been focused on pharmacokinetics and gastrointestinal motor effects of novel acetylcholinesterase modulators in experimental pigs (Bureš et al. 2013, 2014b, Kuneš et al. 2014, Žd'árová Karasová et al. 2013). The aim of this study was 
to evaluate the impact of basic cholinergic and anticholinergic agents on porcine EGG in a standardized protocol.

\section{Material and Methods}

\section{Animals and study design}

Six experimental mature female pigs (Sus scrofa f. domestica, hybrids of Czech White and Landrace breeds; 3-4-months old; mean weight 31.2 \pm 2.1 , median $30.9 \mathrm{~kg}$ ) entered the study twice. All pigs were consecutively given atropine and neostigmine, always after a one-week washout period. Animals were fed twice a day (standard assorted food A1) and were allowed free access to water. All EGG recordings were performed under general anesthesia in the morning after $24 \mathrm{~h}$ of fasting. Intramuscular injections of ketamine (20 mg per kg; Narkamon, Spofa, Praha, Czech Republic) and azaperone (2.2 mg per kg; Stresnil, Janssen Animal Health, Saunderton, UK) were used as an introduction. General anesthesia was carried out by isoflurane (Flurane, Abbott, Queenborough, UK) that was delivered by mask: inhalation $2 \%$ isoflurane in medicinal oxygen (2 liters per min). A 10-min baseline EGG was recorded $20 \mathrm{~min}$ after general anesthesia started. After the baseline period animals were administrated atropine (1.5 mg i.m.; Atropini sulfas monohydricus; Biotika Bohemia) and after a one-week washout period they were administrated neostigmine (0.5 mg i.m.; Neostigmini metilsulfas; Hoechst). After the baseline, EGG followed by a $90-\mathrm{min}$ trial recording in both groups.

\section{Electrogastrography}

We used our own methods of porcine EGG described elsewhere (Tachecí et al. 2013). Briefly, six active self-adhesive high-quality electrodes were placed on the upper part of the abdomen, the 7 th electrode (basal) was placed left of the middle sternum (Fig. 1). Electrodes were arranged for mutual bipolar recording. A special abdominal belt (respiratory sensor) was used to identify possible artefacts due to breathing and body movements (see Fig. 1). Surface cutaneous EGG was recorded using an Electrogastrography Stand Alone System (MMS - Medical Measurement Systems B.V., Enschede, the Netherlands). This highly sophisticated device has appropriate amplifiers and filters so that it is able to execute, secure and process the 50 to $500 \mu \mathrm{V}$ EGG signal that ranges from 1 to 15 cycles per min (cpm). The EGG recording is filtered digitally to remove unwanted frequencies such as 0.5 -cpm ultraslow pattern and respiratory or cardiac rhythms. MMS software (version 8.19) was used to assess EGG recordings. Running spectral analysis was used for the evaluation (Koch and Stern 2004). Results were expressed as dominant frequency of slow waves of EGG recordings. EGG power was assessed as areas of amplitudes. Individual one-min intervals were used for all evaluation.

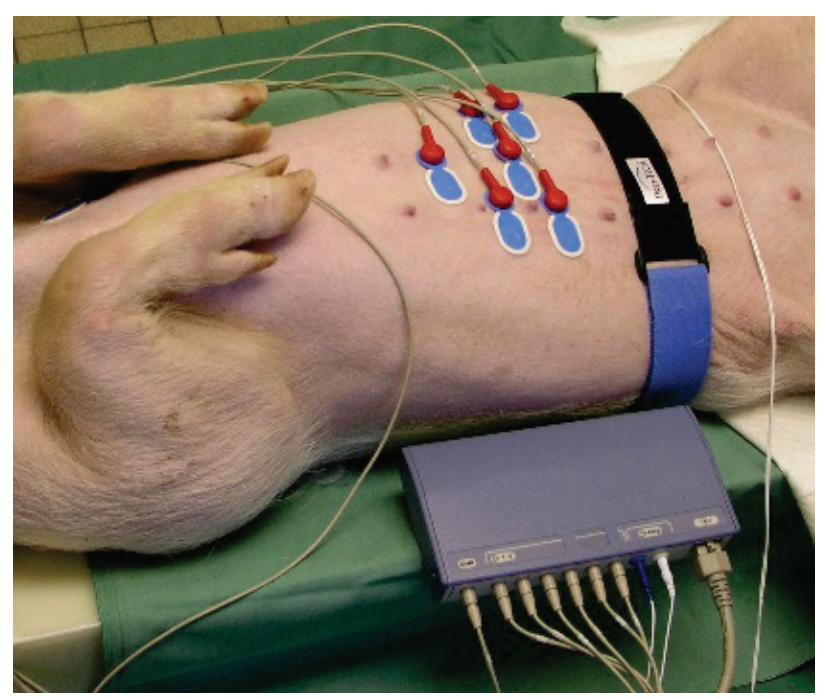

Fig. 1. Detailed view of the placement of 7 electrodes and a special abdominal belt (functioning as a respiratory sensor).

\section{Statistical analysis}

The data were analyzed using SigmaStat software (Version 3.1, Jandel Corp., Erkrath, Germany). Standard normal distribution of data was assessed first. Particular EGG parameters before and after the drug administration were tested. Number of one-min EGG intervals was different in particular groups that is why non-paired t-test was tried. If normality testing failed, non-parametric Mann-Whitney rank sum test continued.

\section{Ethics}

The Project was approved by the Institutional Review Board of the Animal Care Committee of the University of Defence, Faculty of Military Health Services, Hradec Kralove, Czech Republic, Protocol Number 14/12 (2012). Animals were held and treated in accordance with the European Convention for the Protection of Vertebrate Animals Used for Experimental and Other Scientific Purposes (Council of Europe, 2009).

\section{Results}

Basic results are shown in Figures 2-5. 
Neostigmine increased continuously the dominant frequency from basal EGG $2.58 \pm 0.54 \mathrm{cpm}$ up to $2.86 \pm 0.61$ at the 60-90-min interval $(\mathrm{p}<0.001)$. Neostigmine decreased significantly the EGG power (594.3 $\pm 853.8 \mu \mathrm{V}^{2}$ at the 5-10-min interval, $\mathrm{p}=0.036$, throughout to the 60-90-min interval, $117.6 \pm 157.5 \mu \mathrm{V}^{2}$; $\mathrm{p}<0.001$ ). Atropine did not change the dominant

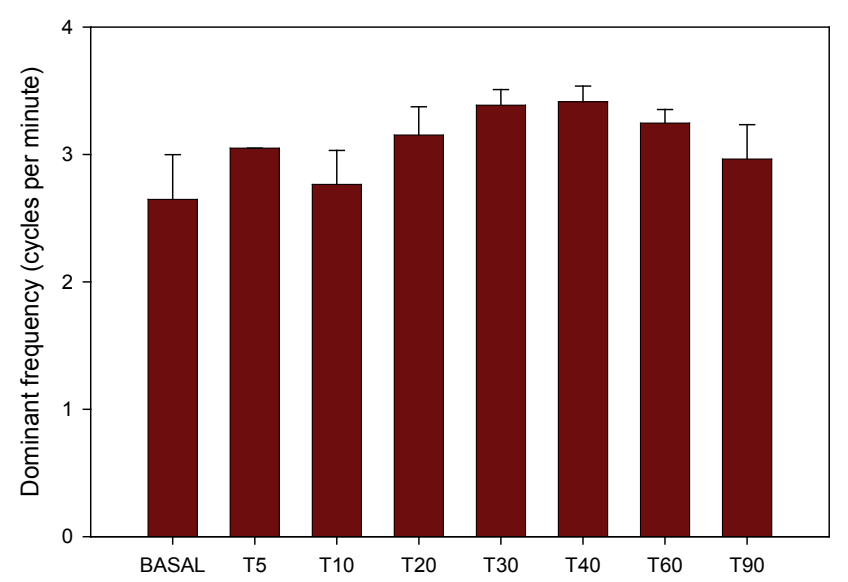

Fig. 2. Effect of atropine on dominant frequency in porcine electrogastrography. Basal: a 10-min basal EGG recording before i.m. administration of atropine. T5: EGG recording at time interval between the $1^{\text {st }}-5^{\text {th }}$ min after i.m. administration of atropine; T10: interval 6-10 min; T20: 11-20 min; T30: 21-30 min; T40: 31-40 min; T60: 41-60 min; T90: 61-90 min

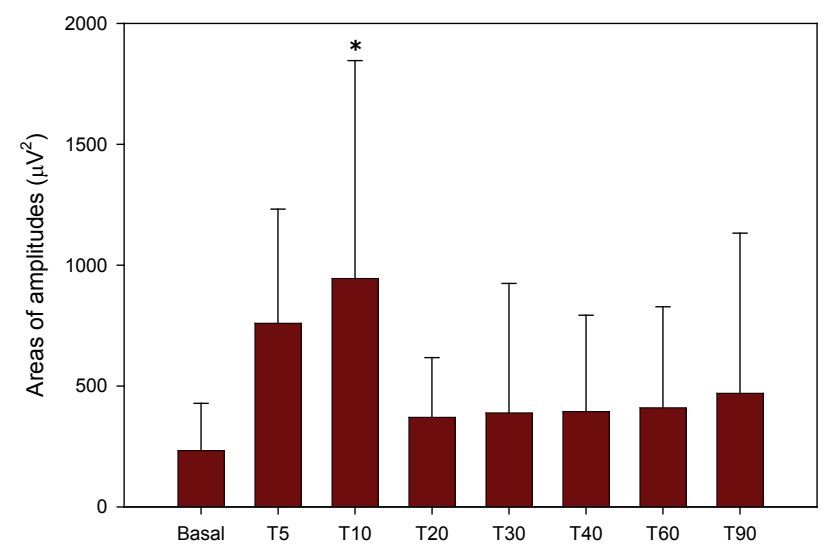

Fig. 4. Effect of atropine on EGG power (areas of amplitudes) in porcine electrogastrography. Basal: a 10-min basal EGG recording before i.m. administration of atropine. T5: EGG recording at time interval between the $1^{\text {st }}-5^{\text {th }}$ min after i.m. administration of atropine; T10: interval 6-10 min; T20: 11-20 min; T30: 21-30 min; T40: 31-40 min; T60: 41-60 min; T90: 6190 min. $* \mathrm{p}<0.001$

\section{Discussion}

Our current study brought new important data on the impact of basic cholinergic and anticholinergic agents on porcine EGG. Pigs can be used in various preclinical frequency significantly. However, atropine increased significantly the EGG power (areas of amplitudes) from basal values $(232.5 \pm 195.9)$ to the maximum at the $10-20$ min interval $\left(945.0 \pm 901.2 \mu \mathrm{V}^{2} ; \mathrm{p}<0.001\right)$. After that period, the areas of amplitudes decreased significantly to the values of $409.8 \pm 417.9 \mu \mathrm{V}^{2}$ at the $60-90$-min interval $(\mathrm{p}=0.001)$.

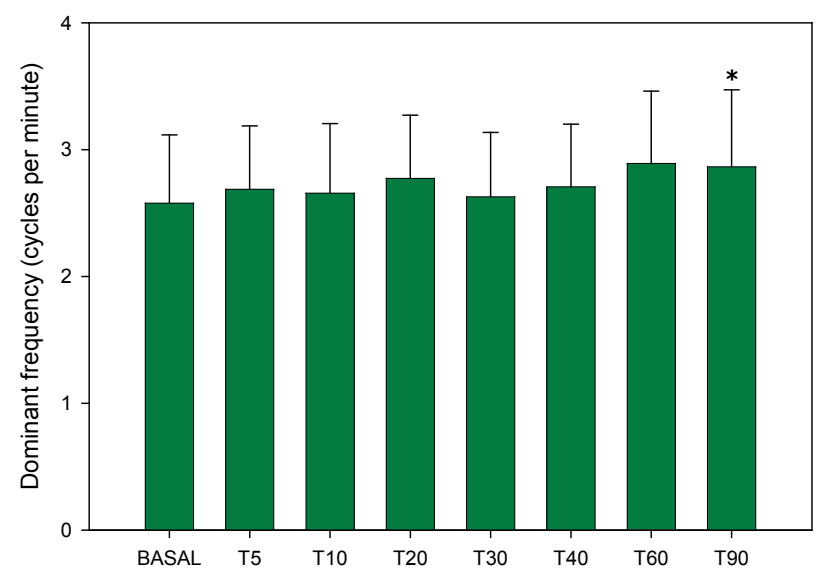

Fig. 3. Effect of neostigmine on dominant frequency in porcine electrogastrography. Basal: a 10-min basal EGG recording before i.m. administration of neostigmine. T5: EGG recording at time interval between the $1^{\text {st }}-5^{\text {th }}$ min after i.m. administration of neostigmine; T10: interval 6-10 min; T20: 11-20 min; T30: 21-30 min; T40: 31-40 min; T60: 41-60 min; T90: 61-90 min. $* \mathrm{p}<0.001$

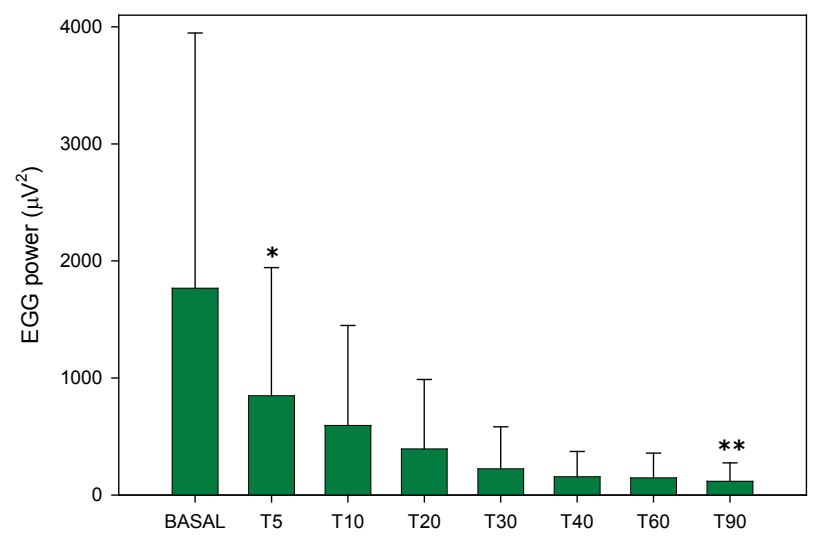

Fig. 5. Effect of neostigmine on EGG power (areas of amplitudes) in porcine electrogastrography. Basal: a 10-min basal EGG recording before i.m. administration of neostigmine. T5: EGG recording at time interval between the $1^{\text {st }}-5^{\text {th }}$ min after i.m. administration of neostigmine; T10: interval 6-10 min; T20: $11-$ 20 min; T30: 21-30 min; T40: 31-40 min; T60: 41-60 min; T90: $61-90$ min. $* \mathrm{p}=0.036, * * \mathrm{p}<0.001$

experiments as an omnivorous representative due to their relatively very similar gastrointestinal functions compared to humans (Kararli 1995, Suenderhauf and Parrott 2013). Neostigmine is a parasympathomimetic that acts as a reversible acetylcholinesterase inhibitor. By 
interfering with the breakdown of acetylcholine, neostigmine indirectly stimulates both nicotinic and muscarinic receptors. Its half-life in humans is about 50-90 min (Neostigmine Drug Information, 2015). Atropine, an anticholinergic agent, is a competitive antagonist for the muscarinic acetylcholine receptors. Its half-life in humans is about $2 \mathrm{~h}$ (Atropine Drug Information, 2015). However, very little is still known about the effect of cholinergic and anticholinergic agents on myoelectrical activity of the stomach. Kaneko et al. (1995) found that both vagal and non-vagal cholinergic activity influenced postprandial EGG (mostly amplitudes) in healthy volunteers. Katoh et al. (2003) studied the effect of glucagon and scopolamine butylbromide. The peak power amplitudes significantly decreased and dominant frequency increased in both groups. Parkman et al. (1999) studied low doses of atropine and bethanechol in humans. Ten healthy adult volunteers received intravenous bolus of $0.6 \mathrm{mg}$ atropine and then a $15-\mathrm{min}$ low-dose i.v. infusion (by rate $0.25 \mathrm{mg} / \mathrm{h}$ ). In that setting, atropine caused a slight increase in gastric myoelectrical activity by EGG. Bethanechol slightly increased the amplitude, but slightly decreased the frequency of gastric myoelectrical activity by EGG (Parkman et al. 1999). However, EGG recording lasted only $15 \mathrm{~min}$ in the Parkman's study. Authors did not mention body weight of volunteers. If we assume that mean body weight was about $75 \mathrm{~kg}$, they used 5-times lower doses than we did.

We have shown different early impact of atropine and neostigmine. Atropine produced a significant initial increase of the EGG power (with maximum at $10 \mathrm{~min}$ after i.m. administration) with a subsequent gradual decrease. Neostigmine caused a significant continuous decrease of EGG power compared to the basic recording. This different effect illustrates the possible vagal and non-vagal cholinergic impact in the control of gastric myoelectric activity in experimental pigs. It has been known that cholinergic stimulation increases slow wave frequency (Koch and
Stern 2004). Kim et al. (2003) studied muscarinic regulation of pacemaker frequency in murine gastric interstitial cells of Cajal and they found that acetylcholine increased the frequency of slow waves in gastric muscles. High concentrations of carbachol may block the entrainment of pacemaker currents (Kim et al. 2003). Neostigmine, as an indirect stimulator of nicotinic and muscarinic receptors, increased significantly the dominant frequency in our current study, but still within normal range, while atropine did not reveal any significant effect in this aspect. Nevertheless, we are aware of possible drawbacks of the study and that is why it is necessary to interpret our results with cautions. There is a great inter-individual variability of EGG in particular pigs. To reduce this impact and to minimize possible bias we related all trial parameters to basal values before the study drugs administration. Large amount of data acquired from one-minute intervals allowed reliable statistical analysis. We applied a standardized protocol using the same isoflurane general anesthesia. Thus our results could be considered as credible.

\section{Conclusions}

Both cholinergic and anticholinergic agents affect differently EGG in experimental pigs. These basic data are mandatory for the proper future evaluation of preclinical gastrointestinal motor effects of novel acetylcholinesterase modulators in experimental pigs.

\section{Conflict of Interest}

There is no conflict of interest.

\section{Acknowledgements}

The study has been supported by an independent research grant from Internal Grant Agency of Ministry of Health of the Czech Republic No. NT/14270. This study was presented in part at the 91st Physiological Days, February 2015, Brno, Czech Republic.

\section{References}

Atropine: Drug Information. UpToDate online (vol. 22.1.), Wolters Kluwer, Alphen aan den Rijn, 2015.

BUREŠ J, KOPÁČOVÁ M, VOŘÍŠEK V, BUKAČ J, NEUMANN D, ŽIVNÝ P, PALIČKA V, REJCHRT S: Correlation of electrogastrography and gastric emptying rate estimated by ${ }^{13} \mathrm{C}$-octanoic acid breath test in healthy volunteers. Folia Gastroenterol Hepatol 5: 5-11, 2007.

BUREŠ J, KABELÁČ K, KOPÁČOVÁ M, VOŘÍŠEK V, ŠIROKÝ M, PALIČKA V, REJCHRT S: Electrogastrography in patients with Roux-en-Y reconstruction after previous Billroth gastrectomy. HepatoGastroenterology 55: 1492-1496, 2008. 
BUREŠ J, KVĚTINA J, PAVLÍK M, KUNEŠ M, KOPÁČOVÁ M, REJCHRT S, JUN D, HRABINOVÁ M, KUČA M, TACHECÍ I: Impact of paraoxon followed by acetylcholinesterase reactivator HI-6 on gastric myoelectric activity in experimental pigs. Neuro Endocrinol Lett 34 (Suppl 2): 79-83, 2013.

BURES J, KVETINA J, PAVLIK M, KUNES M, KUCA K, KOPACOVA M, REJCHRT S, TACHECI I: Effect of different doses of atropine on the gastric myoelectric activity in experimental pigs. Gastroenterology 146 (Suppl 1): S-267, 2014a.

BURES J, KVETINA J, ZDAROVA KARASOVA J, TACHECI I, PAVLIK M, KUNES M, MUSILEK K, REJCHRT S, DOUDA T, KUCA K, KOPACOVA M: The effect of K027, a novel oxime acetylcholinesterase reactivator, on gastric myoelectric activity assessed by electrogastrography in experimental pigs. UEG $J \mathbf{2}$ (Suppl 1): A569-A570, 2014b.

CHEN JZ: Electrogastrography. Principles and Applications. CHEN JZ, MCCALLUM RW (eds), Raven Press, New York, 1994.

DOUDA T, KVETINA J, TACHECI I, PAVLIK M, KUNES M, KOPACOVA M, REJCHRT S, BURES J: The impact of erythromycin on myoelectric activity in experimental pigs. UEG $J 2$ (Suppl 1): A255, 2014.

Explanatory Report on the European Convention for the Protection of Vertebrate Animals Used for Experimental and Other Scientific Purposes (ETS 123). Council of Europe, Strasbourg, 2009.

JACKSON AL, RASHED H, CARDOSO S, WONG F, WERKMAN R, THOMPSON J, ABELL TL: Assessment of gastric electrical activity and autonomic function among diabetic and nondiabetic patients with symptoms of gastroesophageal reflux. Dig Dis Sci 45: 1727-1730, 2000.

KANEKO H, SAKAKIBARA M, MITSUMA T, MORISE K: Possibility of postprandial electrogastrophagy for evaluating vagal/nonvagal cholinergic activity in humans, through simultaneous analysis of postprandial heart rate variability and serum immunoreactive hormone levels. Am J Gastroenterol 90: 603-609, 1995.

KARARLI TT: Comparison of the gastrointestinal anatomy, physiology and biochemistry of humans and commonly used laboratory animals. Biopharm Drug Dispos 16: 351-380, 1995.

KATOH K, NOMURA M, IGA A, HIASA A, UEHARA K, HARADA K, NAKAYA Y, ITO S: Comparison of gastric peristalsis inhibition by scopolamine butylbromide and glucagon: evaluation by electrogastrography and analysis of heart rate variability. $J$ Gastroenterol 38: 629-635, 2003.

KIM TW, KOH SD, ORDÖG T, WARD SM, SANDERS KM: Muscarinic regulation of pacemaker frequency in murine gastric interstitial cells of Cajal. J Physiol 546: 415-425, 2003.

KOCH KL, STERN RM: Handbook of Electrogastrography. Oxford University Press, Oxford, 2004.

KOENIG JB, MARTIN CE, DOBSON H, MINTCHEV MP: Use of multichannel electrogastrography for noninvasive assessment of gastric myoelectrical activity in dogs. Am J Vet Res 70: 11-15, 2009.

KUNEŠ M, KVĚTINA J, BUREŠ J, ŽĎÁROVÁ KARASOVÁ J, PAVLÍK M: TACHECÍ I, MUSÍLEK K, KUCA K: HI-6 oxime (an acetylcholinesterase reactivator): blood plasma pharmacokinetics and organ distribution in experimental pigs. Neuro Endocrinol Lett 35 (Suppl 2): 186-191, 2014.

KVĚTINA J, VARAYIL JE, ALI SM, KUNEŠ M, BUREŠ J, TACHECÍ I, REJCHRT S, KOPÁČOVÁ M: Preclinical electrogastrography in experimental pigs. Interdiscip Toxicol 3: 53-58, 2010.

MINTCHEV MP, KINGMA YJ, BOWES KL: Accuracy of cutaneous recordings of gastric electrical activity. Gastroenterology 104: 1273-1280, 1993.

Neostigmine: Drug Information. UpToDate online (vol. 22.1.), Wolters Kluwer, Alphen aan den Rijn, 2015.

O'GRADY G, DU P, EGBUJI JU, LAMMERS WJ, WAHAB A, PULLAN AJ, CHENG LK, WINDSOR JA: A novel laparoscopic device for measuring gastrointestinal slow-wave activity. Surg Endosc 23: 2842-2848, 2009.

PARKMAN HP, TRATE DM, KNIGHT LC, BROWN KL, MAURER AH, FISHER RS: Cholinergic effects on human gastric motility. Gut 45: 346-354, 1999.

PARKMAN HP, HASLER WL, BARNETT JL, EAKER EY; AMERICAN MOTILITY SOCIETY CLINICAL GI MOTILITY TESTING TASK FORCE: Electrogastrography: a document prepared by the gastric section of the American Motility Society Clinical GI Motility Testing Task Force. Neurogastroenterol Motil 15: 89-102, 2003.

SUENDERHAUF C, PARROTT N: A physiologically based pharmacokinetic model of the minipig: data compilation and model implementation. Pharm Res 30: 1-15, 2013. 
TACHECÍ I, KVĚTINA J, KUNEŠ M, VARAYIL JE, ALI SM, PAVLÍK M, KOPÁČOVÁ M, REJCHRT S, BUREŠ J, PLESKOT M: Electrogastrography in experimental pigs: the influence of gastrointestinal injury induced by dextran sodium sulphate on porcine gastric erythromycin-stimulated myoelectric activity. Neuro Endocrinol Lett 32 (Suppl 1): 101-105, 2011.

TACHECÍ I, KVĚTINA J, KUNEŠ M, PAVLÍK M, KOPÁČOVÁ M, ČERNÝ V, REJCHRT S, VARAYIL JE, BUREŠ J: The effect of general anaesthesia on gastric myoelectric activity in experimental pigs. BMC Gastroenterol 13: 48, 2013.

TACHECI I, KVETINA J, PAVLIK M, KUNES M, REJCHRT S, KOPACOVA M, BURES J: Impact of water load test on the gastric myoelectric activity in experimental pigs. Gastroenterology 146 (Suppl 1): S-269, 2014.

VARAYIL JE, ALI SM, TACHECI I, KVETINA J, KOPACOVA M, KUNES M, REJCHRT S, BURES J: Electrogastrography in experimental pigs. Methodical design and initial experience. Folia Gastroenterol Hepatol 7: 98-104, 2009.

ŽĎÁROVÁ KARASOVÁ J, ZEMEK F, KUNEŠ M, KVĚTINA J, CHLÁDEK J, JUN D, BUREŠ J, TACHECÍ I, KUČA K: Intravenous application of HI-6 salts (dichloride and dimethansulphonate) in pigs: comparison with pharmacokinetics profile after intramuscular administration. Neuro Endocrinol Lett 34 (Suppl 2): 74-78, 2013. 